\title{
CHARACTERISTICS OF TRAINING AND ASSOCIATION WITH INJURIES IN RECREATIONAL ROAD RUNNERS
}

\author{
CARACTERISTICAS DO TREINAMENTO EASSOCIAÇÃO A LESÕES EM CORREDORES DE \\ RUARECREACIONAIS
}

Original Article

Artigo OrigINAL

Artículo Original

\section{CARACTERISTICAS DEL ENTRENAMIENTO Y ASOCIACIÓN A LESIONES EN CORREDORES DE CALLERECREATIVOS}

\begin{abstract}
Fernando Carmelo Torres ${ }^{1,2}$ (ID (Physician)

Antonio Carlos Gomes ${ }^{2}$ (DD (Physical Education Professional)

Sergio Gregorio da Silva 3 (ID (Biochemist and Pharmacist)

1. Universidade Federal do Paraná (UFPR), Physical Education Graduate Studies Program, Curitiba, PR, Brazil.

2. Universidade Paulista (UNIP), Center for Exercise Physiology and Training Studies (CEFIT), São Paulo, SP, Brazil.

3. Universidade Federal do Paraná (UFPR), Department of Physical Education, Curitiba, PR, Brazil.
\end{abstract}

\section{Correspondence:}

Fernando Carmelo Torres

Rua Itapimirum, 11, 151 bloco B,

Vila Andrade, São Paulo, SP, Brazil. 05716-090. fernando@cefit.esp.br

\begin{abstract}
Introduction: Road running has been increasing dramatically in Brazil and worldwide for years. However, research into this practice has privileged high performance athletes while neglecting recreational runners, even though they constitute a significant majority of participants. Objectives: This study analyzed the associations between demographic and training characteristics of recreational runners in $5 \mathrm{~km}, 10 \mathrm{~km}$ and half marathon events, and the occurrence of musculoskeletal injuries. Methods: The study used data from 395 adult runners (229 men and 166 women, respectively aged $37.9 \pm 9.5$ and $37.1 \pm 8.7$ years, body weight $77 \pm 10.5$ and $61 \pm 9$ $\mathrm{kg}$, and height $1.75 \pm 0.07 \mathrm{~m}$ and $1.62 \pm 0.07 \mathrm{~m}$ ), who voluntarily and anonymously answered a questionnaire available on the Internet. Results: Plantar fasciitis, chondromalacia patellae (runner's knee) and tibial periostitis were the most frequently mentioned injuries in both sexes. Predisposing factors for injury (longer running time, average weekly mileage, maximum mileage and average speed in a workout) predominated in the male group, which had more types of injury and longer layoffs for this reason. Most respondents (63.3\% men and $60.2 \%$ women) did not perform isolated stretching exercises; in those who did perform these exercises, and in those who stretched before and/or after training for races or competitions, there was no reduction in the incidence of injuries. Conclusion: Men showed a tendency towards greater intensity and volume of race training, in addition to longer running time, which are predisposing factors for injury. This may explain the greater number of different injuries reported in the male group, as well as the longer layoff periods. Level of evidence Il; Prognostic studies - Investigating the effect of patient characteristics on disease outcome.
\end{abstract}

Keywords: Running; Injury; Physical Activity.

\section{RESUMO}

Introdução: Há anos a corrida de rua vem crescendo vertiginosamente no Brasil e no mundo. Entretanto, as pesquisas sobre essa prática têm privilegiado os atletas de alto rendimento, deixando os corredores recreacionais em segundo plano, embora eles sejam a expressiva maioria dos praticantes. Objetivos: Este estudo analisou as associações de características demográficas e de treino de corredores recreacionais em provas de $5 \mathrm{~km}, 10 \mathrm{~km}$ e meia maratona à ocorrência de lesões osteomioarticulares. Métodos: Foram utilizados dados de 395 corredores adultos (229 homens e 166 mulheres, com idade 37,9 $\pm 9,5$ e 37,1 $\pm 8,7$ anos; peso corporal 77 $\pm 10,5$ e $61 \pm 9 \mathrm{~kg}$ e estatura 1,75 $\pm 0,07 \mathrm{me}$ $1,62 \pm 0,07 \mathrm{~m}$, respectivamente) que responderam, voluntária e anonimamente, a questionário disponibilizado na web. Resultados: Fasciite plantar, condromalácia patelar e periostite tibial foram as lesões mais citadas, em ambos os sexos. Os fatores predisponentes de lesão (maior tempo de prática, quilometragem média semanal, quilometragem máxima e velocidade média num treino) predominaram no grupo masculino, que mostrou ocorrência de mais tipos de lesão e de períodos maiores de afastamento da prática por esse motivo. A maioria dos pesquisados (63,3\% homens e 60,2\% mulheres) não fazia treino isolado de alongamento; nos que tinham este hábito e naqueles que se alongavam antes e/ou depois de treinos de corridas ou provas, não houve redução da incidência de lesões. Conclusão: Os homens tinham tendência a maior intensidade e volume de treino de corrida, além de mais tempo de prática, os quais são fatores predisponentes de lesão. Isso pode explicar a maior quantidade de diferentes lesões relatadas no grupo masculino, bem como os maiores períodos de afastamento dos treinos. Nível de evidência Il; Estudos prognósticos - Investigação do efeito de característica de um paciente sobre o desfecho da doença.

Descritores: Corrida; Lesões; Treinamento físico.

\section{RESUMEN}

Introducción: Desde hace años la carrera de calle viene creciendo vertiginosamente, en Brasil y en el mundo. Entretanto, las investigaciones sobre esta práctica han privilegiado a los atletas de alto rendimiento, dejando a los corredores recreativos en segundo plano, aunque ellos sean la mayoría expresiva de los practicantes. Objetivos: Este estudio analizó las asociaciones de características demográficas y de entrenamiento de corredores recreativos en pruebas de $5 \mathrm{~km}, 10 \mathrm{~km}$ y media maratón, con la ocurrencia de lesiones osteomioarticulares. Métodos: Se utilizaron datos de 395 corredores adultos (229 hombres y 166 mujeres, de 37,9 $\pm 9,5$ y 37,1 $\pm 8,7$ años; peso corporal $77 \pm 10,5$ y 
$61 \pm 9 \mathrm{~kg}$; yestatura 1,75 $\pm 0,07 \mathrm{~m}$ y 1,62 $\pm 0,07 \mathrm{~m}$, respectivamente), que respondieron, voluntaria y anónimamente, a un cuestionario disponible en la web. Resultados: La fascitis plantar, la condromalacia rotuliana y la periostitis tibial fueron las lesiones más citadas, en ambos sexos. Los factores predisponentes de lesión (mayor tiempo de práctica, kilometraje promedio semanal, kilometraje máximo y velocidad promedio en un entrenamiento) predominaron en el grupo masculino, que mostró la ocurrencia de más tipos de lesión y períodos más largos de alejamiento de la práctica por ese motivo. La mayoría de los encuestados (63,3\% hombres y 60,2\% mujeres) no realizaba entrenamiento aislado de estiramiento; en aquellos que tenían este hábito y en aquellos que se estiraban antes y/o después de entrenamientos de carrera o pruebas, no hubo reducción de la incidencia de lesiones. Conclusión: Los hombres tenían tendencia a mayor intensidad y volumen de entrenamiento de carrera, además de más tiempo de práctica, los que son factores predisponentes de lesión. Esto puede explicar la mayor cantidad de diferentes lesiones relatadas en el grupo masculino, bien como los mayores períodos de alejamiento de los entrenamientos. Nivel de evidencia ll; Estudios pronósticos - Investigación del efecto de característica de un paciente sobre el desenlace de la enfermedad.

Descriptores: Carrera; Lesión; Entrenamiento físico.

\section{INTRODUCTION}

Road running is an accessible and democratic activity, as it can be performed without the need for expensive equipment or considerable infrastructure and does not necessitate more complex motor skill levels, which has led to its significant growth worldwide. ${ }^{1,2}$ In Brazil, online research has shown that running was the second most popular sport, coming second only to soccer. ${ }^{3}$ Road running is divided into three categories: Marathon (over 42,195 km); Half Marathon (with a distance of 21,097 km); and Other Distances. The latter includes races over standard distances (10 km; 15 km; 20 km; 25 km; 30 km; 100 km; 24-hour Ultramarathon; and Classic Races, over unofficial distances). ${ }^{4}$

Although regular physical exercise, including running, produces physical and mental benefits, ${ }^{5-8}$ inadequate training can have detrimental effects on health, especially injuries, casting doubt about its safety, besides causing commitment issues and/or prompting participants to not only stop running but also to take time off their professional activities. ${ }^{9,10}$ In running, the study of training variables, as they influence performance, is often aimed at elite athletes. On the other hand, the high number of recreational runners, the majority (over 99\%) involved in road running events, ${ }^{2}$ entails the need to conduct further research with this population, which is generally neglected. . $^{11,12}$ Therefore, gleaning a better understanding of the training characteristics of this large group of runners, as proposed here, in addition to the possible correlations with the occurrence of injuries, is an important mission.

Thus, the objectives of this study, with recreational road runners, were as follows: to establish their demographic and training characteristics; identify the most frequent types of musculoskeletal injuries; and verify the association between training variables and the occurrence of these injuries.

\section{MATERIALS AND METHODS}

This is a descriptive correlational cross-sectional study ${ }^{13}$ approved under (Opinion 1.968.226) at the Institutional Review Board of Universidade Federal do Paraná (UFPR).

Participants were experienced runners (in $5 \mathrm{~km}, 10 \mathrm{~km}$ and/or half marathon events), of both sexes, aged $\geq 18$ years, who accessed and voluntarily and anonymously answered, with acceptance of the Informed Consent Form, a questionnaire made available on the Google Drive platform (based on parameters investigated in recent research, with recreational runners, ${ }^{14}$ and expanded in this study), with links disclosed via the internet. The choice of $5 \mathrm{~km}, 10 \mathrm{~km}$ and half marathon runners was due to the fact that they participated in competitions considered of lesser importance with prizes, if any, that were generally much more modest than the marathon and other longer races. Accordingly, this sample would potentially play an important role in representing recreational runners, who are seldom a topic of research in the literature, and constitute the main focus of this study.

Demographic and anthropometric information (age, sex, body weight and height) was requested to identify the sample, in addition to information about the general training routine of the subject: maximum mileage in a workout; weekly averages of frequency, duration, mileage and speed recorded in race training; running time, and the habit of stretching. We also investigated the occurrence of musculoskeletal injuries resulting from running and any layoff periods due to these injuries. This questionnaire involved 23 types of potential running injuries, with two other options to be ticked (I was not injured; Other type of injury), totaling 25 alternatives and allowing respondents to tick as many different injuries as they could.

Except for the open-ended numerical questions about body weight and height, all the others were closed-ended questions.

Exclusion criteria: questionnaires about races with a reported speed of $<2.5$ or $>12.5$ minutes per kilometer; ${ }^{14}$ questionnaires answered by subjects aged under 18; data from open answers that were incompatible with any possible numerical answer; and questionnaires sent with total repetition of answers, for all items (keeping only one of them). A total of 21 questionnaires of the 416 received were excluded as they all contained repeated answers to each of the questions, compared to another questionnaire sent, denoting duplicate submission by the same runner, resulting in 395 participants.

\section{Statistical analysis}

Descriptive statistics were used to characterize the sample and training. Measures of central tendency and dispersion (mean and standard deviation) were used for continuous variables, while relative frequency (\%) was calculated for categorical variables. The Chi-square test for trend was used to verify associations between categorical variables, and ANOVA for comparison between groups. All tests were performed using the statistical software Statistical Package for the Social Sciences (SPSS, version 20.0) for Windows, with significance stipulated at $p<0.05$.

\section{RESULTS}

Of the 395 participants, 229 were men (58\%) and 166 women (42\%). The age of the male group was $37.9 \pm 9.5$ years, with a body weight of $77 \pm 10.5 \mathrm{~kg}$ and height of $1.75 \pm 0.07 \mathrm{~m}$, resulting in a Body Mass Index (BMI) of $24.8 \pm 3.1$; in the female group, the respective values were $37.1 \pm$ 8.7 years, $61 \pm 9 \mathrm{~kg}$ and $1.62 \pm 0.07 \mathrm{~m}$, with a BMl of $22.8 \pm 3.2$. 
Table 1 shows the distribution of runners, by sex, in the investigated periods of length of participation in the sport.

The frequency of three to four weekly running training sessions was predominant in both sexes, involving $55.9 \%$ of men and $63.3 \%$ of women. As regards the duration of training sessions, runners were distributed, similarly and for the most part, in three sequential time bands (in hours), in male and female, respectively: $<1 \mathrm{~h}=28.4 \%$ and $27.7 \%$; $1 \mathrm{~h}=34.1 \%$ and $36.7 \%$; $>1$ to $1.5 \mathrm{~h}=28.4 \%$ and $28.3 \%$ (totaling $90.9 \%$ of men and $92.7 \%$ of women).

Table 2 shows the data for longest distance covered in a single training session and for average running mileage and speed per week.

The habit of performing stretching exercises associated with training or competition was studied with the subjects divided into the following groups (and relative frequencies, for men and women, respectively): those who did not stretch (22.7\% and $16.9 \%)$; those who stretched just before (20.5\% and 19.3\%); those who only stretched afterwards (24.9\% and 28.9\%); and those who stretched before and after running (31.9\% and 34.9\%), the latter predominating in both sexes. When we investigated the execution of an isolated stretching session, at a time distant from training sessions or competitions, a significant portion of runners (male 63.3\%; female 60.2\%) did not perform this type of activity.

In the investigation of musculoskeletal injuries resulting from running, $48.5 \%$ of men reported having sustained one to two types of injury, and $14 \%$ had sustained three or more different injuries (total of $62.5 \%$ injured); in women, $52.4 \%$ had sustained one to two types, and $10.2 \%$ reported three or more (62.6\% injured), with the highest male percentage in the group with $\geq 3$ injuries having a statistically significant difference between the sexes. Table 3 presents the eight types of injury ticked most often in this research project.

Table 1. Running experience (in years): distribution (\%), by sex.

\begin{tabular}{c|c|c|c|c|c|c|c|}
\hline Sex & $\mathbf{5 1}$ & $\mathbf{> 1 - 2}$ & $\mathbf{> 2 - 4}$ & $\mathbf{> 4 - 6}$ & $\mathbf{> 6 - 8}$ & $\mathbf{> 8 - 1 0}$ & $\mathbf{> 1 0}$ \\
\hline Male & 11.4 & 15.3 & 21.0 & 12.7 & 7.9 & 9.6 & 22.3 \\
\hline Female & 15.1 & 22.3 & 24.7 & 15.7 & 5.4 & 6.6 & 10.2 \\
\hline
\end{tabular}

Table 2. Average weekly mileage and maximum mileage per training session; Average speed of running training session: distribution (\%), by sex.

\begin{tabular}{|c|c|c|c|c|c|c|}
\hline & $\mathrm{Km} / \mathrm{wk}$ & $\%$ & $>\mathrm{Km} /$ sess. & $\%$ & Sp. $(\mathrm{km} / \mathrm{h})$ & $\%$ \\
\hline & $\leq 20$ & 23.1 & $\leq 4$ & 3.9 & $\leq 8$ & 6.6 \\
\hline \multirow{10}{*}{ Male } & $>20-30$ & 23.1 & $>4-6$ & 7.4 & $>8-10$ & 17.5 \\
\hline & $>30-40$ & 22.7 & $>6-8$ & 7.9 & $>10-12$ & 41.5 \\
\hline & $>40-50$ & 11.8 & $>8-10$ & 9.2 & $>12-14$ & 19.7 \\
\hline & $>50-60$ & 5.2 & $>10-12$ & 12.7 & $>14-16$ & 9.2 \\
\hline & $>60-70$ & 3.9 & $>12-14$ & 9.2 & $>16-18$ & 1.7 \\
\hline & $>70-80$ & 3.5 & $>14-16$ & 12.2 & $>18-20$ & 0.9 \\
\hline & $>80-90$ & 3.1 & $>16-18$ & 5.7 & $>20$ & 0.4 \\
\hline & $>90-100$ & 2.6 & $>18-20$ & 7.9 & - & - \\
\hline & $>100$ & 0.9 & $>20$ & 24.0 & - & - \\
\hline & $\leq 20$ & 36.7 & $\leq 4$ & 4.2 & $\leq 8$ & 21.7 \\
\hline \multirow{9}{*}{ Female } & $>20-30$ & 34.3 & $>4-6$ & 13.3 & $>8-10$ & 38.0 \\
\hline & $>30-40$ & 17.5 & $>6-8$ & 14.5 & $>10-12$ & 28.9 \\
\hline & $>40-50$ & 6.6 & $>8-10$ & 17.5 & $>12-14$ & 4.8 \\
\hline & $>50-60$ & 1.8 & $>10-12$ & 14.5 & $>14-16$ & 0.6 \\
\hline & $>60-70$ & 1.2 & $>12-14$ & 9.0 & $>16-18$ & 0.0 \\
\hline & $>70-80$ & 0.6 & $>14-16$ & 9.0 & $>18-20$ & 0.0 \\
\hline & $>80-90$ & 0.0 & $>16-18$ & 4.8 & $>20$ & 0.0 \\
\hline & $>90-100$ & 1.2 & $>18-20$ & 4.2 & - & - \\
\hline & $>100$ & 0.0 & $>20$ & 9.0 & - & - \\
\hline
\end{tabular}

$\mathrm{Km} / \mathrm{wk}=$ Average weekly mileage of running training session; $>\mathrm{Km} / \mathrm{sess}$. = Highest mileage in a training session; $S p .=$ Average speed in the running training session, in $\mathrm{km} / \mathrm{h}$; Training session time $=$ Total weekly duration of the running training session, in hours; \%: Relative frequency.
Table 4 shows a direct association between longer running times and the development of injuries. The highest percentage of runners who had been participating in the sport for $\leq 1$ year falls within the bracket of those who did not report running-related injuries, a situation similar to those who had been running for $>1$ to 2 years. As we move on to longer periods of participation, the predominant percentages shift to the group with one to two different injuries reported, with a gradual increase in percentages in the bracket of three or more injuries, with statistical significance.

As regards the average total weekly mileage and the occurrence of injuries, there was statistical significance in this association, showing that a longer distance accumulated weekly in training sessions appears to be correlated with injuries in runners. As shown in Table 5, the group in the lowest total weekly mileage bracket ( $\leq 20 \mathrm{~km} /$ week) had the highest percentage (52.6\%) of runners reporting absence of running-related injuries. As we analyzed the groups with increasing weekly distances, we noticed that most of the members of these groups had changed category to the brackets with presence of injuries, predominantly for those who reported one to two injuries.

As regards the different types of injury sustained, men and women, respectively, were categorized as follows: $37.5 \%$ and $37.4 \%$ with no injury; $48.5 \%$ and $52.4 \%$ reporting one or two types; and $14 \%$ and $10.2 \%$ with $\geq 3$ types (Figure 1 ).

Among runners reporting injuries and who had to stop training, $83.5 \%$ males and $78.9 \%$ females discontinued the activity for this reason. It is interesting to note that $4.6 \%$ of women diagnosed with an injury

Table 3. Main injuries resulting from running - \% of total injuries mentioned, by sex.

\begin{tabular}{c|c|c|c}
\hline Injury & Male & Injury & Female \\
\hline $\begin{array}{c}\text { Plantar } \\
\text { Fasciitis }\end{array}$ & 14.8 & $\begin{array}{c}\text { Plantar } \\
\text { Fasciitis }\end{array}$ & 13.9 \\
\hline $\begin{array}{c}\text { Chondromalacia } \\
\text { Patellae }\end{array}$ & 9.6 & $\begin{array}{c}\text { Chondromalacia } \\
\text { Patellae }\end{array}$ & 12.8 \\
\hline $\begin{array}{c}\text { Tibial periostitis } \\
\text { (shin splints) }\end{array}$ & 8.9 & $\begin{array}{c}\text { Tibial periostitis } \\
\text { (shin splints) }\end{array}$ & 11.7 \\
\hline Calf strain & 8.9 & $\begin{array}{c}\text { Bursitis/ } \\
\text { Synovitis/Tendonitis - hip }\end{array}$ & 7.2 \\
\hline $\begin{array}{c}\text { Iliotibial band syndrome } \\
\text { Tendonitis - hip }\end{array}$ & 7.0 & \|liotibial band syndrome & 6.1 \\
\hline $\begin{array}{c}\text { Bursitis/Synovitis/ } \\
\text { Tendonitis - Achilles }\end{array}$ & 5.5 & $\begin{array}{c}\text { Lower back pain (w/ } \\
\text { out herniated disc) }\end{array}$ & 6.1 \\
\hline $\begin{array}{c}\text { Lower back pain } \\
\text { (w/out herniated disc) }\end{array}$ & 4.8 & Posterior tibial tendonitis & 5.6 \\
\hline
\end{tabular}

Table 4. Running experience $x$ Injuries - distribution (\%) among participants.

\begin{tabular}{c|c|c|c}
\hline Experience (years) & No injury* & 1 to injuries** $^{* *}$ & $\mathbf{2 3}$ injuries** \\
\hline$\leq 1$ & 52.9 & 45.1 & 2.0 \\
\hline$>1$ to 2 & 50.0 & 40.3 & 9.7 \\
\hline$>2$ to 4 & 38.2 & 55.1 & 6.7 \\
\hline$>4$ to 6 & 29.1 & 52.7 & 18.2 \\
\hline$>6$ & 27.3 & 53.1 & 19.5 \\
\hline
\end{tabular}

* Significance for Increasing running experience (Chi square; $p<0.01$ ).

Table 5. Weekly mileage (Km/wk) x Injuries - distribution (\%) among participants.

\begin{tabular}{|c|c|c|c|}
\hline $\mathrm{Km} / \mathrm{wk}$ & No Injury* & 1 to 2 Injuries* & $\geq 3$ Injuries* \\
\hline$\leq 20$ & 52.6 & 40.4 & 7.0 \\
\hline 21 to 30 & 32.7 & 55.5 & 11.8 \\
\hline 31 to 40 & 28.4 & 55.6 & 16.0 \\
\hline 41 to 50 & 42.1 & 42.1 & 15.8 \\
\hline 51 to 60 & 20.0 & 60.0 & 20.0 \\
\hline$\geq 61$ & 27.0 & 56.8 & 16.2 \\
\hline
\end{tabular}

* Significance for increasing weekly distances (Chi square; $p<0.05$ ). 
Table 6. Distribution (\%) among injured subjects in the training layoff periods, by sex.

\begin{tabular}{c|c|c|c|c|c}
\hline Sex & $\mathbf{5 1} \mathbf{2 k}$ & $\mathbf{> 1} \mathbf{w k}-\mathbf{1} \mathbf{~ m}$ & $\mathbf{> 1 - 2} \mathbf{~ m}$ & $\mathbf{> 2 - 3} \mathbf{~ m}$ & $>\mathbf{3 ~} \mathbf{~}$ \\
\hline Male & 7.9 & 34.6 & 18.1 & 9.5 & 29.9 \\
\hline Female & 17.4 & 23.3 & 19.8 & 16.3 & 23.2 \\
\hline wk: week; m: month.
\end{tabular}

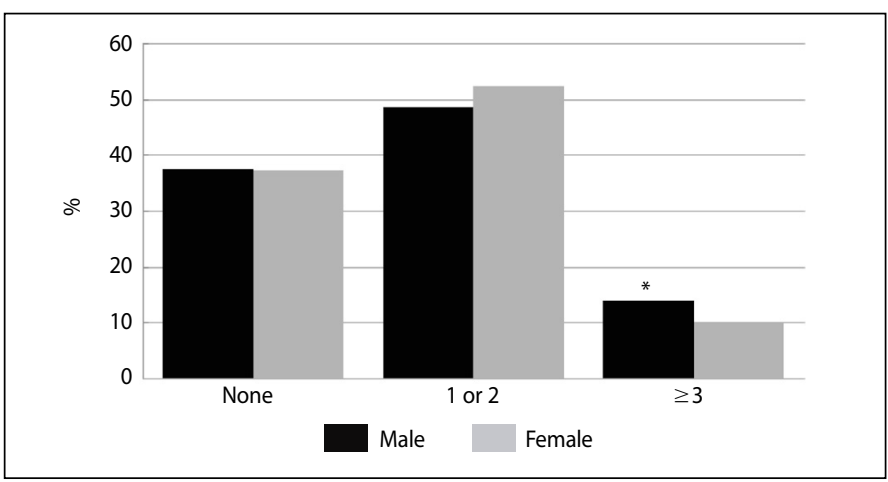

Figure 1. Relative frequency of runners with and without occurrence of different types of injury, by sex.

reported having received medical guidance for layoff, but disobeyed (if they had followed the advice, we would have $83.5 \%$ layoff in both sexes). Table 6 shows the relative distribution of injured subjects, by sex, in the different layoff periods. In women, the highest percentages were in the $>1$ week to 1 month (23.3\%) and > 3 month (23.2\%) layoff brackets; in men, the largest group (34.6\%) was also in the $>1$ week to 1 month bracket, followed by $29.9 \%$ of injured subjects within the longest layoff period of the questionnaire ( $>3$ months). This percentage is statistically higher than that found in women, in the same bracket.

The analysis of responses, by sex, about which type of injury produced the longest running layoff time, indicated the predominance of the following injuries in the male group: Plantar fasciitis (13.9\%), Chondromalacia patellae and Strains (distension) of the calf muscles (both with 11.5\%), Iliotibial band syndrome (8.2\%) and Tibial periostitis (shin splints) (6.6\%). In the female group: Chondromalacia patellae (14.1\%), Tibial periostitis (shin splints) (11.8\%), Tibial stress fracture (9.4\%), Meniscus injury (8.2\%) and Bursitis/Synovitis/Tendonitis of the hip (7.1\%).

\section{DISCUSSION}

The demographic and anthropometric data of the sample proved to be similar to those of research carried out with a significant number of these runners. ${ }^{14}$ The greater participation of male subjects in the sample was also observed in a recent review involving Brazilian recreational runners. ${ }^{11}$

Men proved more experienced than women in this particular study. The male group with the highest concentration of runners included the men who had been running for more than 10 years (22.3\%). In the women, the largest group was in the $>2$ to 4 year (24.7\%) bracket, followed by runners with $>1$ to 2 years of experience.

In the average weekly training mileage, in men, predominant and similar percentages were distributed over distances up to $40 \mathrm{~km}$, totaling 67.9\%. Among women, $71 \%$ were concentrated in the two lowest mileages studied, with $36.7 \%$ in the $\leq 20 \mathrm{~km}$ bracket. It is important to note, in this regard, that in a recent meta-analysis, a weekly distance greater than $20 \mathrm{~km}$ is a predictive variable of injuries. ${ }^{11}$ For the maximum distance in a single training session, men exhibited greater concentration (24.0\%) in the group that covered more than $20 \mathrm{~km}$, with women having a higher percentage (17.5\%) in a shorter distance bracket (>8 to $10 \mathrm{~km}$ ).

Regarding the average speed of training sessions, among male subjects, the largest group (41.5\%) ran at a pace of $>10$ to $12 \mathrm{~km} / \mathrm{h}$, with $87.9 \%$ distributed in the brackets between $>8$ and $10 \mathrm{~km} / \mathrm{h}$ and $>14$ to
$16 \mathrm{~km} / \mathrm{h}$; among the female subjects, the majority (38.0\%) trained at a lower speed (>8 to $10 \mathrm{~km} / \mathrm{h}$ ), with $86.8 \%$ belonging to groups with a comparatively lower average pace (between $\leq 8 \mathrm{~km} / \mathrm{h}$ and $>10$ to 12 $\mathrm{km} / \mathrm{h}$ ). These data showed that, in the male group, training tends to be more intense and runners achieve higher mileages (weekly average and maximum per session) in training sessions.

As regards to injuries, the similar total percentage of injured subjects, for both sexes, fall within prevalence ranges found in review studies with runners (Borel et al. ${ }^{11}$ - 20 to 65.9\%; Van Gent et al..$^{15}$ - 19.4 to $79.3 \%$; Von Der Worp et al. ${ }^{16}$ - 20.6 to $\left.79.3 \%\right)$. The prevalence of injuries in these runners varies widely in the literature, and appears to be related to the different designs, methodologies and protocols used in research projects. ${ }^{17,18}$ For the running-related injuries studied, it was noted that the three injuries with the highest percentage of occurrence were coincident, for both sexes. Specifically, plantar fasciitis has the highest percentages, both in male and female subjects, which can be explained by the fact that people who train and compete in long distance races would tend to generate and accumulate high rates of pressure in the plantar region, favoring the appearance of this type of injury. ${ }^{19}$ Although there is no consensus in the literature on the most prevalent injury in pedestrians, ${ }^{11,20-22}$ with authors agreeing that they predominantly affect the lower limbs, a study by McKean et al. ${ }^{20}$ also presented plantar fasciitis, which is the most frequently mentioned injury in our sample, as having the highest incidence in runners. Among the eight most frequently mentioned injuries, six are listed for men and women, and the three most frequent injuries are the same, showing a certain pattern in the type of injury sustained by runners, irrespective of sex. However, among injured runners, the highest percentages presented in men, for the group that reported having sustained $\geq 3$ different injuries, and also in the longest layoff range reported ( $>3$ months), suggest a greater occurrence and severity of this incident in male subjects. This may be due to the fact that men have factors known to be correlated with the development of injuries, as seen in this and other studies, such as training with greater intensity and/or volume, 11,21,23,24 besides the chronic effect of longer running time.$^{25}$ One assumption is that the highly repetitive and cumulative effect of stress caused by the impact of strides while running over the years, could increase the chance of injury. In addition, over time, it is expected that the progressive development of the runner will give rise to a tendency to increase both running speed and mileage, factors also considered to be predisposing, as discussed above.

The habit of performing stretching exercises associated with the training session or competition, regardless of the time of execution, was not effective in preventing injuries, which is consistent with other findings in the literature. ${ }^{24,26,27}$ This was also observed, in this research project, for the group that reported the performance of specific isolated training sessions for flexibility.

\section{CONCLUSIONS}

The demographic and anthropometric characteristics were similar to studies involving the participation of a large number of subjects and that targeted this population. Men showed a tendency to engage in training of greater intensity and volume in addition to longer running times, which are factors associated with the appearance of injuries. Although the main injuries reported were similar in both sexes, these predisposing factors, in the male group, may explain the greater number of different types of injuries reported in these runners, as well as the longer injury-related layoff periods.

It is important to emphasize that, although the gathering of information through a questionnaire, without the presence and assistance of the investigators, may be subject to some restrictions, other alternatives, 
such as that of attempting to collect answers in person at testing sites, appeared to us to be a worse option, not only because of the inconvenience of approaching the competitor at a time when they are concentrating and focusing on the race, but also due to data such as, for example, time in previous races, which are sometimes not memorized by the runner and ready to be correctly announced instantly. The fact that the collection of data exclusively involves people with Internet access cannot be considered a cause of considerable bias. Practically all the official competitions held in Brazil and in the rest of the world have online entry, and results are published on the respective websites of the organizers. This shows that practically all these competitors are Internet users, which does not seem to imply an important restriction of access to the questionnaire of this study.

All authors declare no potential conflict of interest related to this article

AUTHORS' CONTRIBUTIONS: Each author made significant individual contributions to this manuscript. FCT: intellectual concept, drafting of the research project, data collection, data analysis, writing and review; ACG: intellectual concept, drafting of the research project, statistical analysis; SGS: intellectual concept, drafting and supervision of the research project. All authors reviewed and approved the final version of the article.

\section{REFERENCES}

1. Fuziki MK. Corrida de rua: fisiologia, treinamentos e lesões. São Paulo: Phorte; 2012.

2. Salgado JV, Chacon-Mikahil MP. Corrida de rua: análise do crescimento do número de provas e de praticantes. Rev Conexões. 2006;4(1):90-9.

3. Deloitte TT. Muito além do futebol: estudo sobre esporte no Brasil [Internet]. 2011 [acesso em 2020 mai 19]. Disponivel em: http://pt.slideshare.net/JCOnLine/pesquisa-esportes-deloitte-2011-apresentao-completa.

4. Confederação Brasileira de Atletismo. Normas Oficiais - Norma 7: Reconhecimento e homologação de corridas de rua [Internet]. 2020 [acesso em 2020 mai 19]. Disponível em: http://www.cbat.org.br/repositorio/cbat/documentos_oficiais/normas_oficiais/norma07_reconhecimentocorridasderua_2020.pdf.

5. Garber CE, Blissmer B, Deschenes MR, Franklin BA, Lamonte MJ, Lee IM et al. American College of Sports Medicine Position Stand. Quantity and quality of exercise for developing and maintaining cardiorespiratory, musculoskeletal, and neuromotor fitness in apparently healthy adults: guidance for exercise prescription. Med Sci Sports Exerc. 2011;43(7):1334-59.

6. Pedisic Z, Shrestha N, Kovalchik S, Stamatakis E, Liangruenrom N, Grgic J, et al. Is running associated with a lower risk of all-cause, cardiovascular and cancer mortality, and is the more the better? A systematic review and meta-analysis. Br J Sports Med. 2019.

7. Morgan WP, Costill DL. Selected psychological characteristics and health behaviors of aging marathon runners: a longitudinal study. Int J Sports Med. 1996;17(4):305-12.

8. Suter E, Marti B, Tschopp A, Wanner HU. Effects of jogging on mental well-being and seasonal mood variations: a randomized study with healthy women and men. Schweiz Med Wochenschr. 1991;121(35):1254-63.

9. Smits DW, Huisstede B, Verhagen E, van derWorp H, Kluitenberg B, van Middelkoop M, et al. Short-Term Absenteeism and Health Care Utilization Due to Lower Extremity Injuries Among Novice Runners: A Prospective Cohort Study. Clin J Sport Med. 2016;26(6);502-9.

10. Hespanhol Junior LC, van Mechelen W, Verhagen E. Health and economic burden of running-related injuries in dutch trailrunners: a prospective cohort study. Sports Med. 2017;47(2):367-77.

11. Borel WP, Elias Filho J, Diz JB, Moreira PF, Veras PM, Catharino LL, et al. Prevalência de lesões em corredores de rua amadores brasileiros: metanálise. Rev Bras Med Esporte. 2019;25(2):161-7.

12. Seiler S, Tønnessen E. Intervals, thresholds, and long slow distance: the role of intensity and duration in endurance training. Sport Sci. 2009;13:1-27.

13. Thomas JR, Nelson JK, Silverman SJ. Métodos de pesquisa em atividade física. $6^{a}$ ed. Porto Alegre: Artmed; 2012
14. Vickers AJ, Vertosick EA. An empirical study of race times in recreational endurance runners. BMC Sports Sci Med Rehabil. 2016;8(1):26.

15. van Gent RN, Siem D, van Middelkoop M, van Os AG, Bierma-Zeinstra SM, Koes BW. Incidence and determinants of lower extremity running injuries in long distance runners: a systematic review. $\mathrm{Br}$ J Sports Med. 2007;41(8):469-80.

16.van der Worp MP, ten Haaf DS, van Cingel R, De Wijer A, Nijhuis-van der Sanden MW, Staal JB. Injuries in runners: a systematic review on risk factors and sex differences. PLoS One. 2015;10(2):e0114937.

17. van Mechelen W. Running injuries. A review of the epidemiological literature. Sports Med. 1992;14(5):320-35

18. Yamato TP, Saragiotto BT, Hespanhol Junior LC, Yeung SS, Lopes AD. Descriptors used to define a running-related musculoskeletal injury: a systematic review. J Orthop Sports Phys Ther. 2015;45(5):366-74

19. Schmidt A, Bankoff AD. Análise da distribuição da pressão plantar em corredores de longa distância. Rev Digital. 2011;16(160)

20. McKean KA, Manson NA, Stanish WD. Musculoskeletal injury in the masters runners. Clin J Sport Med. 2006;16(2):149-54.

21. Hespanhol Jr LC, Costa LO, Carvalho AC, Lopes AD. Perfil das características do treinamento e associação com lesões musculoesqueléticas prévias em corredores recreacionais: um estudo transversal. Rev Bras Fisioter. 2012;16(1):46-53

22. Souza CA, Aquino FA, Barbosa ML, Alvarez RB, Turienzo TT. Principais lesões em corredores de rua. Rev UNILUS Ens Pesq. 2013;10(20):35-41.

23. Taunton JE, Ryan MB, Clement DB, McKenzie DC, Lloyd-Smith DR, Zumbo BD. A prospective study of running injuries: the Vancouver sun run "in training" clinics. Br J Sports Med. 2003;37(3):239-44.

24. Fredericson M, Misra AK. Epidemiology and an etiology of marathon running injuries. Sports Med. 2007;37(4-5):437-9

25. Rangel GM, Farias JM. Incidência de lesões em praticantes de corrida de rua no município de Criciúma, Brasil. Rev Bras Med Esporte. 2016;22(6):496-500.

26. Shrier I. Stretching before exercise does not reduce the risk of local muscle injury: a critical review of the clinical and basic science literature. Clin J Sports Med. 1999;9(4):221-7.

27. Pope RP, Herbert RD, Kirwan JD, Graham BJ. A randomizecl trial of pre-exercise stretching for prevention of lower-limb injury. Med Sci Sports Exerc. 2000;32(2):271-7. 